\title{
Investigation of the origin and distribution of heavy metals around Ebenezer Dam, Limpopo Province, South Africa
}

\author{
JS Ogola'*, HR Mundalamo ${ }^{1}$ and G Brandl ${ }^{2}$ \\ ${ }^{1}$ Department of Mining and Environmental Geology, School of Environmental Sciences, University of Venda, \\ Private Bag X 5050, Thohoyandou 0950, South Africa \\ ${ }^{2}$ Council for Geoscience, PO Box 620, Polokwane 0700, South Africa
}

\begin{abstract}
This study was based on the outcome of the soil geochemical survey which was conducted by the Council for Geoscience around Ebenezer Dam during 1995-1996, the results of which indicated high concentrations of lead (Pb), zinc $(\mathrm{Zn})$ and arsenic (As). The current study therefore focused on the origin and distribution patterns of $\mathrm{Pb}, \mathrm{Zn}, \mathrm{Cu}, \mathrm{As}$ and $\mathrm{Cr}$ within the environs of Ebenezer Dam and their potential impacts on the environment and human health. The work involved soil, sediment, rock and water sampling and analysis. Atomic absorption and x-ray fluorescence spectrometry were used to determine the metal concentrations. The occurrence of anomalous concentrations of these metals in the study area was established. The anomalies registered maximum concentrations of (mg/g): 57 for Pb, 157 for $\mathrm{Zn}, 313$ for $\mathrm{Cu}, 73$ for As and 888 for $\mathrm{Cr}$. The concentrations of these metals in sediments along the streams were high near the anomalies, but decreased downstream. Concentrations of heavy metals in water around the Ebenezer Dam were found to be less than $0.01 \mathrm{mg} / \mathrm{g}$, except for As which was less than $1.0 \mathrm{mg} / \mathrm{g}$. Thus $\mathrm{Pb}, \mathrm{Zn}, \mathrm{Cu}$ and $\mathrm{Cr}$ values were below the target water quality ranges for domestic, irrigation, livestock watering and aquatic ecosystem use. The study confirmed that the distribution of heavy metals in this area is localised within and around the source rocks that are felsic in nature, namely; granites and pegmatites that formed domes in the area.
\end{abstract}

Keywords: Ebenezer Dam, heavy metals, distribution patterns, anomalies

\section{Introduction}

Concern over the effects of heavy metals on the environment and human health is increasing with rapid economic development and population growth. Exploitation of mineral resources, agricultural activities and urbanisation result in disturbance of the natural environment and water pollution. This, in conjunction with natural geological processes, leads to the release of elements/metals into the environment. Most of these heavy metals are re-deposited and concentrated in soils, surface water and groundwater (Plant et al., 1996).

Geochemistry, particularly, the surface distribution and concentration of trace elements, can be difficult to predict from geological maps (Simpson et al., 1991). Thus, in many developed countries, such as Britain, Canada, Scandinavia and Australia, geochemical mapping has been incorporated into the strategic systematic geoscience survey, which uses geochemical data to prepare modern geochemical maps in line with the International Geochemical Baseline. In developing countries there is an urgent need for high resolution geochemical data which are adequate for environmental and epidemiological studies (WHO, 1998).

The Council for Geoscience of South Africa has already embarked on such projects in a number of provinces and this project was a follow-up to this work, being based on the outcome of research conducted in the area around Ebenezer Dam. The area was sampled during 1995-1996 and the soil analysis from this area indicated high concentrations of lead $(\mathrm{Pb})$, zinc

\footnotetext{
* To whom all correspondence should be addressed.

용 +2715 962 8511; fax: +27159628597;

e-mail: ogolaj@univen.ac.za

Received 28 April 2010; accepted in revised form 1 February 2011
}

(Zn) and arsenic (As) (Szczesniak et al., 2001). The recommendation from this initial work was that a detailed investigation needed to be done in order to establish the nature and source of geochemical anomalies and their impacts on the environment.

The Ebenezer area, which covers Haenertsburg town and the Ebenezer Dam, is found about $60 \mathrm{~km}$ to the east of Polokwane city and lies between $23^{\circ} 48^{\prime} 00^{\prime \prime}$ and $24^{\circ} 00^{\prime} 00^{\prime \prime}$ latitude and $29^{\circ} 52^{\prime} 00^{\prime \prime}$ and $30^{\circ} 06^{\prime} 00^{\prime}$ longitude (Fig. 1). The area is densely forested, mountainous and has fenced farms and plantations. The dam covers about $66 \mathrm{~km}^{2}$. The dam water is mainly used for domestic, agricultural, livestock and recreational purposes.

\section{Materials and analytical techniques}

Soil sampling: Initial sampling covered the entire study area at an interval of $500 \mathrm{~m}$ along defined grids. About $2 \mathrm{~kg}$ of soil samples were collected (50 samples) at a depth of $10-15 \mathrm{~cm}$. This was later followed by detailed soil sampling of targets at $100 \mathrm{~m}$ intervals along profiles, $200 \mathrm{~m}$ apart, and a total of 52 samples was collected.

Sediment sampling: This involved sampling along streams that cut through or run close to the anomalous targets, including those that feed Ebenezer Dam (Fig. 2). A total of 30 sediment samples were collected along the streams at an interval of $200 \mathrm{~m}$, each sample weighing about $2 \mathrm{~kg}$.

Water sampling: Water samples were collected along the shoreline of the dam and upstream at an interval of $200 \mathrm{~m}$ from the shoreline (Fig. 2). Ten samples were collected in $250 \mathrm{~m} \ell$ bottles. Before sampling, the water bottle was rinsed with water to be sampled, and the $\mathrm{pH}$ and electrical conductivity readings 


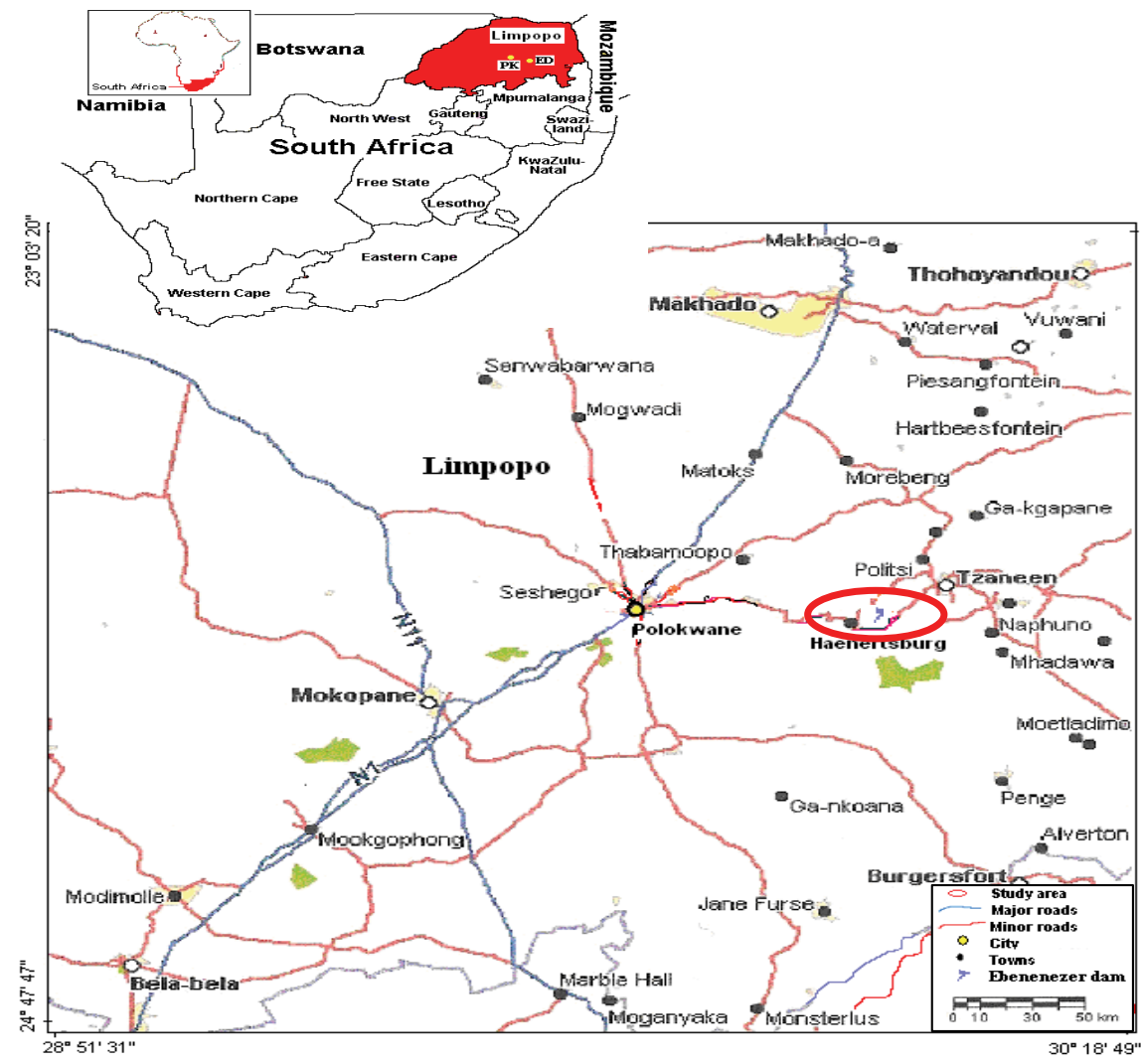

Figure 1

Location map of the

Ebenezer Dam and its environs (Source:

Google maps)

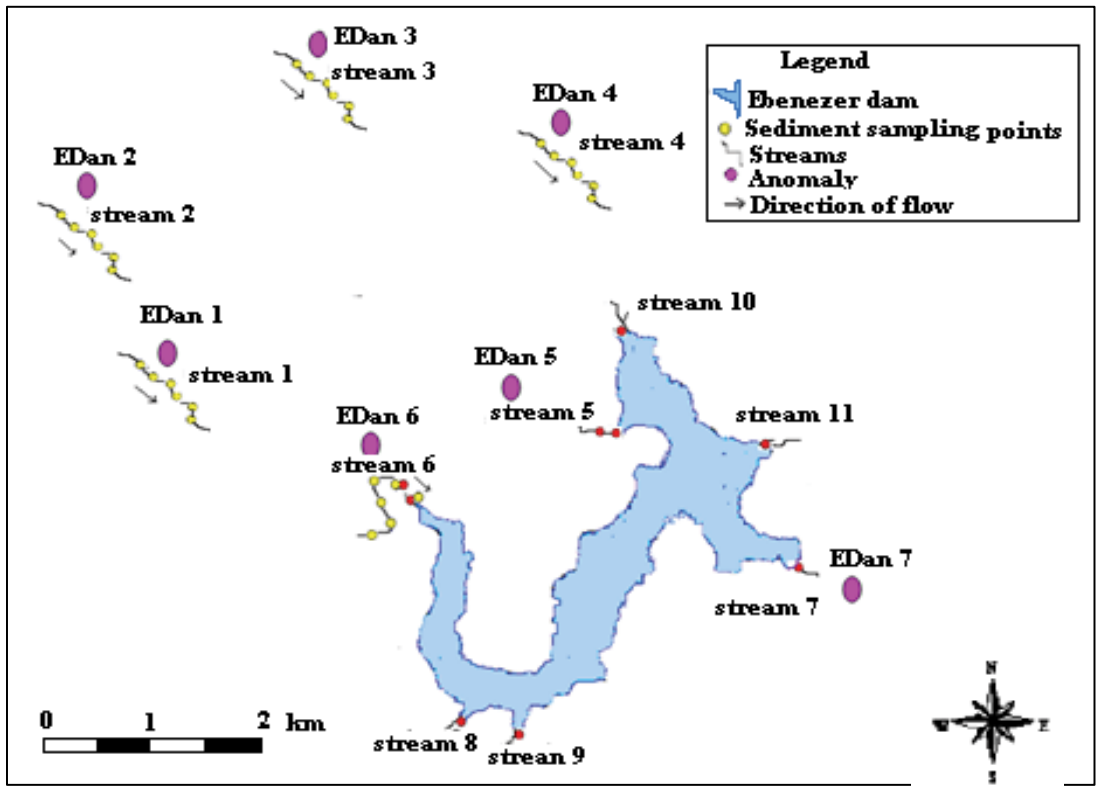

Figure 2

A sketch map of sediment and water sampling points in Ebenezer area

were taken, using a WTW Multi 340i meter. The $\mathrm{pH}$ meter was first calibrated using standard buffers of $\mathrm{pH} 7$ and $\mathrm{pH} 4$. Electrical conductivity (EC) measurements were obtained by immersing a conductivity electrode into each water sample and leaving the electrode to stabilise for about $2 \mathrm{~min}$. The electrodes were rinsed with distilled water after each sample.

Rock sampling: The concentrations of heavy metals in the soil were used to plot the anomaly map for $\mathrm{Pb}, \mathrm{Zn}, \mathrm{Cu}$, As and $\mathrm{Cr}$. These resulted in the identification of 5 targets from which 5 rock specimens were collected for further analysis.
Sample preparation and analysis: Soil and sediment samples were dried and milled into powder form. The samples were then digested, using aquaregia ( 1 part $\mathrm{HNO}_{3}+3$ parts $\mathrm{HCl}$ by volume) and analysed, using atomic absorption spectrometry (AAS). Water samples were also analysed for $\mathrm{Pb}, \mathrm{Zn}, \mathrm{Cu}, \mathrm{As}$ and $\mathrm{Cr}$, using the same instrument; de-ionised water was used as a blank. Rock samples were crushed and milled into powder form then analysed, at the Council for Geoscience in Pretoria, using x-ray fluorescence spectrometry. The international dolerite reference materials (SARM 50) were used. The results of these analyses are presented in Tables 1, 2, 3 and 4. 
Table 1

Results of concentrations of heavy metals in soils, sediments and rocks (mg/g)

\begin{tabular}{|c|c|c|c|c|c|c|c|c|c|c|c|c|c|c|c|c|c|c|}
\hline \multirow{3}{*}{$\begin{array}{l}\begin{array}{l}\text { Heavy } \\
\text { metals }\end{array} \\
\mathrm{Pb} \\
\end{array}$} & \multicolumn{9}{|c|}{ Anomaly 1} & \multicolumn{9}{|c|}{ Anomaly 2} \\
\hline & \multirow{2}{*}{\begin{tabular}{|c|} 
Rock \\
34 \\
\end{tabular}} & \multirow{2}{*}{$\begin{array}{c}\text { Soil } \\
10 \\
\end{array}$} & \multicolumn{6}{|c|}{ Sediments (Stream 1) } & mean & \multirow{2}{*}{\begin{tabular}{c|} 
Rock \\
1 \\
\end{tabular}} & \multirow{2}{*}{$\begin{array}{c}\text { Soil } \\
10 \\
\end{array}$} & \multicolumn{6}{|c|}{ Sediments (Stream 2) } & mean \\
\hline & & & 7 & 12 & 14 & 12 & 8 & 5 & 10 & & & 9 & 11 & 5 & 8 & 11 & 5 & 8 \\
\hline $\mathrm{Zn}$ & 12 & 30 & 41 & 30 & 41 & 49 & 22 & 25 & 35 & 2 & 22 & 15 & 30 & 20 & 34 & 40 & 17 & 26 \\
\hline $\mathrm{Cu}$ & 4.6 & 43 & 62 & 38 & 66 & 74 & 47 & 54 & 57 & 3.9 & 32 & 12 & 18 & 12 & 18 & 30 & 14 & 17 \\
\hline As & 3 & 4 & 18 & 30 & 26 & 34 & 20 & 6 & 22 & 3 & 4 & 20 & 10 & 18 & 14 & 8 & 12 & 14 \\
\hline $\mathrm{Cr}$ & 21 & 77 & 71 & 119 & 137 & 96 & 92 & 50 & 94 & 6.8 & 54 & 29 & 89 & 26 & 38 & 43 & 25 & 42 \\
\hline \multirow{2}{*}{$\begin{array}{l}\text { Heavy } \\
\text { metal }\end{array}$} & \multicolumn{9}{|c|}{ Anomaly 3} & \multicolumn{9}{|c|}{ Anomaly 4} \\
\hline & Rock & Soil & \multicolumn{6}{|c|}{ Sediments (Stream 3) } & mean & Rock & Soil & \multicolumn{5}{|c|}{ Sediments (Stream 4) } & & mean \\
\hline $\mathrm{Pb}$ & 32 & 11 & 8 & 5 & 5 & 4 & 7 & 5 & 8 & 1 & 9 & 9 & 10 & 9 & 9 & 5 & 7 & 8 \\
\hline $\mathrm{Zn}$ & 4.8 & 17 & 27 & 15 & 24 & 33 & 24 & 15 & 28 & 105 & 25 & 41 & 32 & 30 & 44 & 22 & 27 & 33 \\
\hline $\mathrm{Cu}$ & 3.6 & 38 & 26 & 14 & 18 & 16 & 20 & 23 & 32 & 192 & 50 & 65 & 41 & 4 & 40 & 20 & 36 & 40 \\
\hline As & 3 & 4 & 14 & 18 & 18 & 18 & 12 & 14 & 17 & 3 & 4 & 10 & 8 & 4 & 8 & 18 & 8 & 9 \\
\hline $\mathrm{Cr}$ & 16.3 & 167 & 106 & 110 & 88 & 41 & 55 & 85 & 72 & 67 & 192 & 208 & 203 & 324 & 250 & 119 & 211 & 219 \\
\hline \multirow{2}{*}{$\begin{array}{l}\text { Heavy } \\
\text { metal }\end{array}$} & \multicolumn{9}{|c|}{ Anomaly 6} & & & & & & & & & \\
\hline & Rock & Soil & \multicolumn{6}{|c|}{ Sediments (Stream 6) } & mean & & & & & & & & & \\
\hline $\mathrm{Pb}$ & 13 & 8 & 18 & 3 & 4 & 6 & 5 & 7 & 7 & & & & & & & & & \\
\hline $\mathrm{Zn}$ & 34 & 60 & 54 & 17 & 38 & 44 & 31 & 38 & 37 & & & & & & & & & \\
\hline $\mathrm{Cu}$ & 8.8 & 98 & 54 & 12 & 46 & 53 & 34 & 32 & 39 & & & & & & & & & \\
\hline As & 3 & 4 & 42 & 22 & 12 & 12 & 18 & 14 & 20 & & & & & & & & & \\
\hline $\mathrm{Cr}$ & 15 & 135 & 121 & 181 & 72 & 107 & 187 & 83 & 125 & & & & & & & & & \\
\hline
\end{tabular}

Table 2

Heavy metal concentrations, $\mathrm{pH}$ and electrical conductivity measurements of water from Ebenezer Dam

\begin{tabular}{|c|c|c|c|c|c|c|c|c|c|c|c|c|c|}
\hline & \multicolumn{9}{|c|}{ Heavy metal concentrations $(\mathrm{mg} / \mathrm{g})$ at $26^{\circ} \mathrm{C}$} & \multicolumn{4}{|c|}{$\begin{array}{c}\text { Target water quality range for water use in } \\
\mathrm{mg} / \mathrm{g} \text { (DWAF, 1996) }\end{array}$} \\
\hline & $\begin{array}{l}\text { Stream } \\
\quad 5\end{array}$ & $\begin{array}{l}\text { Stream } \\
\quad 6\end{array}$ & $\begin{array}{l}\text { Stream } \\
7\end{array}$ & $\begin{array}{l}\text { Stream } \\
8\end{array}$ & $\begin{array}{l}\text { Stream } \\
9\end{array}$ & $\begin{array}{l}\text { Stream } \\
10\end{array}$ & $\begin{array}{c}\text { Stream } \\
11\end{array}$ & Blank & Average & Domestic & Irrigation & \begin{tabular}{|c|} 
Livestock \\
watering
\end{tabular} & $\begin{array}{c}\text { Aquatic } \\
\text { ecosystem }\end{array}$ \\
\hline $\mathrm{Pb}$ & $<0.01$ & $<0.01$ & $<0.01$ & $<0.01$ & $<0.01$ & $<0.01$ & $<0.01$ & $<0.01$ & & 0.01 & 0.2 & 0.1 & 0.01 \\
\hline $\mathrm{Zn}$ & $<0.01$ & $<0.01$ & $<0.01$ & $<0.01$ & $<0.01$ & $<0.01$ & $<0.01$ & $<0.01$ & & 3 & 1 & 20 & 2 \\
\hline $\mathrm{Cu}$ & $<0.01$ & $<0.01$ & $<0.01$ & $<0.01$ & $<0.01$ & $<0.01$ & $<0.01$ & $<0.01$ & & 1 & 2 & 10 & 1.4 \\
\hline As & $<1$ & $<1$ & $<1$ & $<1$ & $<1$ & $<1$ & $<1$ & $<1$ & & 0.01 & 0.1 & 1 & 0.05 \\
\hline $\mathrm{Cr}$ & $<0.01$ & $<0.01$ & $<0.01$ & $<0.01$ & $<0.01$ & $<0.01$ & $<0.01$ & $<0.01$ & & 0.05 & 0.1 & 1 & 20 \\
\hline $\mathrm{pH}$ & 7.5 & 7.4 & 7.4 & 7.5 & 7.3 & 7.4 & 7.6 & - & 7.4 & \multicolumn{4}{|c|}{$6.5-8.4$} \\
\hline $\begin{array}{l}\mathrm{EC} \\
\mathrm{mS} / \mathrm{m}\end{array}$ & 68 & 94 & 54 & 69 & 70 & 50 & 46 & - & 64.5 & \multicolumn{4}{|c|}{$0-70 \mathrm{mS} / \mathrm{m}$} \\
\hline
\end{tabular}

\begin{tabular}{|c|c|c|c|c|c|c|c|c|}
\hline \multicolumn{9}{|c|}{$\begin{array}{c}\text { Table } 3 \\
\text { Major oxides (wt \%) of rock samples collected in the Ebenezer area }\end{array}$} \\
\hline \multirow{2}{*}{$\begin{array}{l}\text { Major } \\
\text { Oxides }\end{array}$} & \multicolumn{5}{|c|}{ Sample ID } & \multicolumn{2}{|c|}{ SARM 50} & \multirow{2}{*}{$\begin{array}{l}\text { Standard } \\
\text { deviation }\end{array}$} \\
\hline & $\begin{array}{c}\text { Feldspathic } \\
\text { Pegmatite } \\
\text { (EDr 1) }\end{array}$ & $\begin{array}{l}\text { Quartzite } \\
\text { (EDr 2) }\end{array}$ & $\begin{array}{l}\text { Pegmatite } \\
\text { (EDr 3) }\end{array}$ & $\begin{array}{l}\text { Leuco- } \\
\text { granite } \\
\text { (EDr 4) }\end{array}$ & $\begin{array}{l}\text { Granite } \\
\text { (EDr 6) }\end{array}$ & Results & Certified & \\
\hline $\mathrm{SiO}_{2}$ & 73.22 & 98.90 & 76.99 & 68.84 & 71.24 & 51.22 & 51.56 & 0.2404 \\
\hline $\mathrm{TiO}_{2}$ & 0.08 & 0.02 & 0.05 & 0.17 & 0.28 & 0.83 & 0.86 & 0.0212 \\
\hline $\mathrm{Al}_{2} \mathrm{O}_{3}$ & 14.97 & 0.41 & 14.65 & 17.26 & 15.97 & 15.19 & 15.28 & 0.0636 \\
\hline $\mathrm{Fe}_{2} \mathrm{O}_{3}(\mathrm{t})$ & 1.03 & 0.73 & 0.87 & 0.53 & 2.41 & 11.05 & 11.0 & 0.0354 \\
\hline $\mathrm{MnO}$ & 0.015 & 0.011 & 0.015 & 0.043 & 0.030 & 0.175 & 0.170 & 0.0035 \\
\hline $\mathrm{MgO}$ & 0.16 & 0.06 & 0.07 & 0.06 & 0.72 & 7.51 & 7.57 & 0.0424 \\
\hline $\mathrm{CaO}$ & 0.37 & 0.02 & 0.33 & 0.52 & 2.49 & 10.82 & 10.8 & 0.0141 \\
\hline $\mathrm{Na}_{2} \mathrm{O}$ & 2.94 & 0.08 & 2.99 & 5.05 & 5.04 & 2.13 & 2.30 & 0.1202 \\
\hline $\mathrm{K}_{2} \mathrm{O}$ & 6.82 & 0.03 & 5.26 & 6.16 & 1.39 & 0.65 & 0.61 & 0.0283 \\
\hline $\mathrm{P}_{2} \mathrm{O}_{5}$ & 0.023 & 0.006 & 0.020 & 0.017 & 0.095 & 0.163 & 0.150 & 0.0092 \\
\hline $\mathrm{Cr}_{2} \mathrm{O}_{3}$ & 0.003 & 0.004 & 0.004 & $<0.001$ & 0.005 & 0.047 & 0.052 & 0.0035 \\
\hline L.O.I. & 0.26 & 0.11 & 0.35 & 1.10 & 0.84 & -0.15 & -0.89 & 0.5233 \\
\hline Total & 99.89 & 100.17 & 101.61 & 99.75 & 100.50 & 99.63 & 99.46 & 0.1202 \\
\hline $\mathrm{H}_{2} \mathrm{O}^{-}$ & 0.22 & 0.13 & 0.35 & 0.53 & 0.28 & 0.18 & & 0.0212 \\
\hline
\end{tabular}

SARM-50 is an international dolerite reference material from MINTEK 
Table 4

\begin{tabular}{|c|c|c|c|c|c|c|c|}
\hline \multicolumn{8}{|c|}{$\begin{array}{c}\text { Table } 4 \\
\text { Trace element concentrations }(\mathrm{mg} / \mathrm{g}) \text { of rocks collected in the Ebenezer area with } \\
\text { mean trace element abundance of major rock types }(\mathrm{mg} / \mathrm{g}),(\text { Krauskopf, 1967; } \\
\text { Rose et al., 1979; Alloway et al., 1997) }\end{array}$} \\
\hline \multirow{2}{*}{$\begin{array}{l}\text { Heavy } \\
\text { metals }\end{array}$} & \multirow{2}{*}{$\begin{array}{c}\text { Granitic } \\
\text { igneous } \\
\text { rocks }\end{array}$} & \multirow{2}{*}{$\begin{array}{c}\text { Mafic } \\
\text { igneous } \\
\text { rocks }\end{array}$} & \multicolumn{5}{|c|}{ Results of specimen collected } \\
\hline & & & $\begin{array}{c}\text { Feldspathic } \\
\text { Pegmatite } \\
\text { EDr } 1\end{array}$ & $\begin{array}{l}\text { Quartzite } \\
\text { (EDr 2) }\end{array}$ & $\begin{array}{l}\text { Pegmatite } \\
\text { (EDr 3) }\end{array}$ & $\begin{array}{l}\text { Leuco- } \\
\text { granite } \\
\text { (EDr 4) }\end{array}$ & $\begin{array}{l}\text { Granite } \\
\text { (EDr 6) }\end{array}$ \\
\hline As & 1.5 & 1.5 & $<4$ & $<4$ & $<4$ & $<4$ & $<4$ \\
\hline $\mathrm{Co}$ & 1 & 35 & 2.3 & 1.7 & 2.2 & 1.3 & 5.7 \\
\hline $\mathrm{Cr}$ & 4 & 200 & 5.7 & 6.8 & $<3$ & 6.9 & 15 \\
\hline $\mathrm{Cu}$ & 13 & 90 & 4.6 & 3.9 & 3.6 & 2.6 & 8.8 \\
\hline Mo & 2 & 1 & $<2$ & $<2$ & $<2$ & $<2$ & $<2$ \\
\hline $\mathrm{Pb}$ & 24 & 3 & 34 & $<2$ & 32 & 24 & 13 \\
\hline $\mathrm{Se}$ & 0.05 & 0.05 & $<1$ & $<1$ & $<1$ & $<1$ & $<1$ \\
\hline TI & 1.1 & 0.08 & $<3$ & $<3$ & $<3$ & $<3$ & $<3$ \\
\hline $\mathrm{U}$ & 4.4 & 0.43 & $<2$ & $<2$ & 2.3 & $<2$ & $<2$ \\
\hline $\mathrm{W}$ & 1.5 & 0.36 & $<3$ & $<3$ & $<3$ & $<3$ & $<3$ \\
\hline $\mathrm{Zn}$ & 52 & 100 & 12 & $<3$ & 4.8 & 8.2 & 34 \\
\hline
\end{tabular}

GSS-1 is a soil reference material from IGGE, China
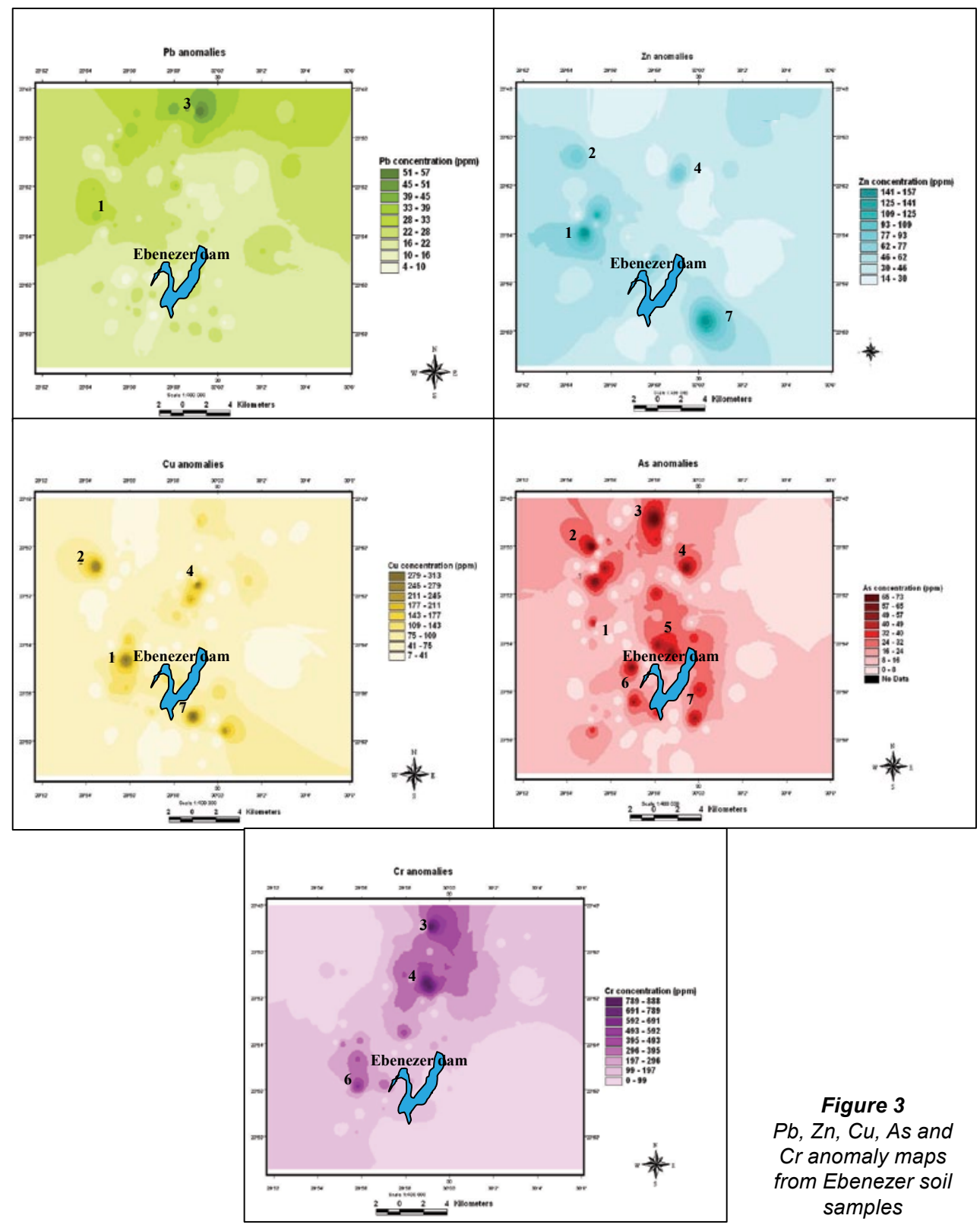

Figure 3

$\mathrm{Pb}, \mathrm{Zn}, \mathrm{Cu}, \mathrm{As}$ and

Cr anomaly maps from Ebenezer soil samples 


\section{Results and discussion}

\section{Concentrations of heavy metals in soils, sediments} and rocks

Concentrations of $\mathrm{Pb}, \mathrm{Zn}, \mathrm{Cu}, \mathrm{As}$ and $\mathrm{Cr}$ in soils were used to plot the anomalous map using ArcView 3.2 software (Fig. 3), from which the location map of these anomalies with reference to the dam was deduced (Fig. 4). The concentrations of $\mathrm{Zn}$, $\mathrm{Cu}, \mathrm{As}$ and $\mathrm{Cr}$ were found to be higher in soils and sediments but lower in rocks, with the exception of rock sample EDr 4 at Anomaly 4 (Fig. 5).

A comparison of the distribution pattern of heavy metals along the profiles over the anomalies showed a general increase in concentration from the base, along the slope, to the top part of the domes. For example, $\mathrm{Zn}$ distribution along the profiles over Anomaly 1 showed an increase in concentration from the base $(25 \mathrm{mg} / \mathrm{g})$, along the slope $(30 \mathrm{mg} / \mathrm{g})$ and at the top $(39 \mathrm{mg} / \mathrm{g}$ ) of the anomaly (Table 5 and Fig. 6). However, along Profile P3 there was a lower $\mathrm{Zn}$ value on the Southern slope of the anomaly. The stream registered higher concentrations near the anomaly and a decrease downstream. For example, $\mathrm{Zn}$ in Stream 1 had a concentration of $41 \mathrm{mg} / \mathrm{g}$ near the anomaly, but this decreased to $25 \mathrm{mg} / \mathrm{g}$ downstream (Table 1).

\begin{tabular}{|l|c|c|c|c|}
\hline \multicolumn{5}{|c|}{ Table 5 } \\
\multicolumn{2}{|c|}{ Zn concentrations in soils along profiles at Anomaly 1 } \\
\hline & $\mathbf{P 1}$ & $\mathbf{P 2}$ & $\mathbf{P 3}$ & Average \\
\hline Base $_{1}\left(\mathrm{~B}_{1}\right)$ & 22 & 29 & 23 & 25 \\
\hline Slope $_{1}\left(\mathrm{~S}_{1}\right)$ & 29 & 33 & 19 & 27 \\
\hline Top part $(\mathrm{T})$ & 46 & 37 & 34 & 39 \\
\hline Slope $_{2}\left(\mathrm{~S}_{2}\right)$ & 37 & 31 & 31 & 33 \\
\hline Base $_{2}\left(\mathrm{~B}_{2}\right)$ & 29 & 24 & 25 & 26 \\
\hline
\end{tabular}

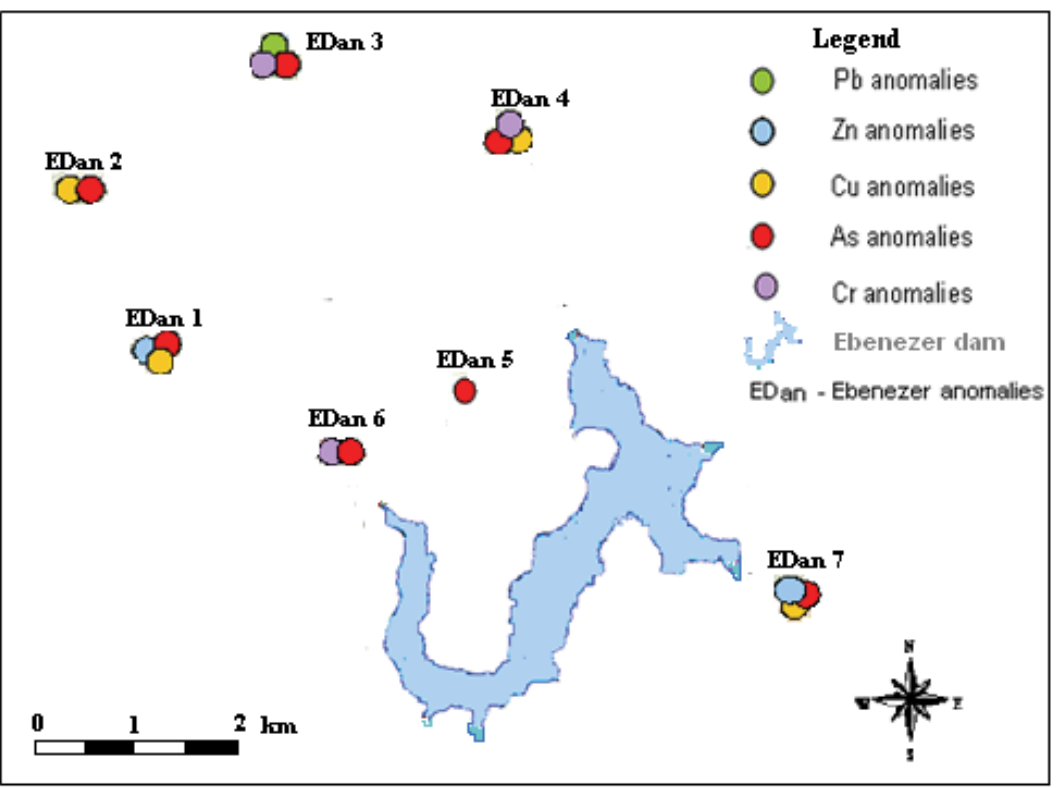

Figure 4

Location map of heavy metal anomalies

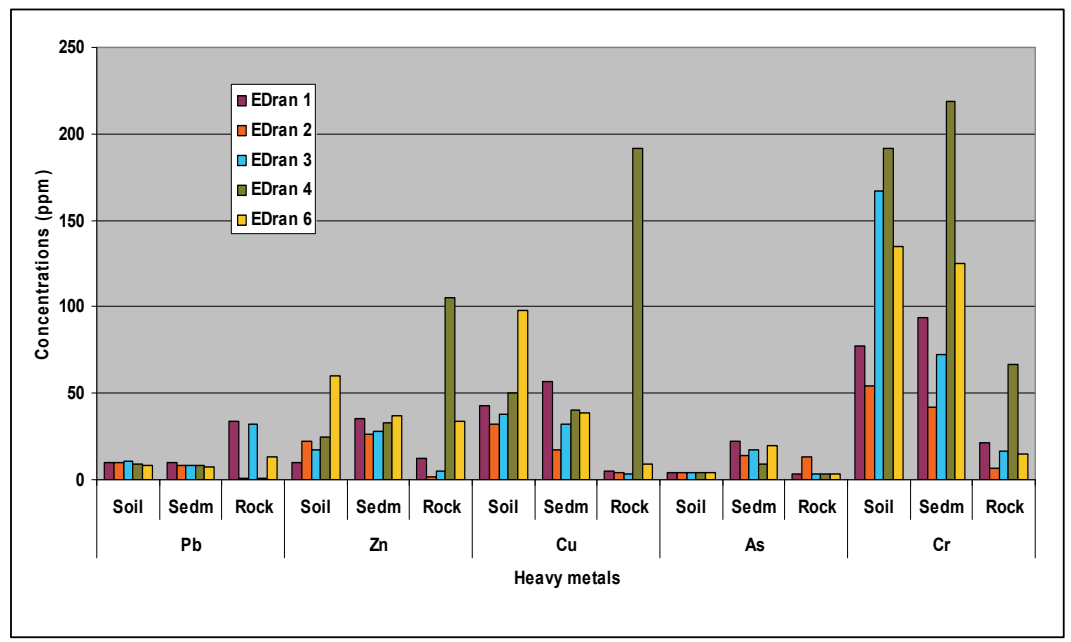

Figure 5

Concentrations of heavy metals in soils, sediments and rocks

\section{Heavy metal concentrations in water}

The concentration values of $\mathrm{Pb}, \mathrm{Zn}, \mathrm{Cu}$ and $\mathrm{Cr}$ in water were found to be below the detection limit $(0.01 \mathrm{mg} / \mathrm{g})$ of the AAS. This was also the case with As $(<$ $1.0 \mathrm{mg} / \mathrm{g}$ ). The concentrations of $\mathrm{Pb}, \mathrm{Zn}$, $\mathrm{Cu}, \mathrm{As}$ and $\mathrm{Cr}$ were compared with the maximum allowable limit for domestic, agricultural, livestock and aquatic ecosystem water quality and $\mathrm{Pb}, \mathrm{Zn}, \mathrm{Cu}$ and $\mathrm{Cr}$ were found to be below the maximum acceptable limit values. At the current level of analysis, the concentration of As in water was less than $1.0 \mathrm{mg} / \mathrm{g}$ and was found to be below the maximum acceptable limit value for livestock use (Table 2).

\section{$\mathrm{pH}$ and electrical conductivity levels in water}

The highest $\mathrm{pH}$ of 7.60 was obtained at the shoreline of Stream 11 on the northeastern part of Ebenezer Dam and the lowest pH of 7.29 was obtained at Stream 9 on the southern part of the dam (Fig. 2). However, the overall assessment of the water $\mathrm{pH}$ indicated an average $\mathrm{pH}$ of 7.4 (Table 2). The $\mathrm{pH}$ of Ebenezer Dam falls within the target water quality range (6.5-8.4) set by DWAF (1996) for domestic, agricultural, livestock and aquatic ecosystem uses (Fig. 7).

The electrical conductivity water quality limit for domestic use is $70 \mathrm{mS} / \mathrm{m}$ (DWAF, 1996). The electrical conductivity for streams flowing into Ebenezer Dam was found to be within the limit for domestic water use $(46-70 \mathrm{mS} / \mathrm{m})$, with the exception of Stream 6 , with a conductivity of $94 \mathrm{mS} / \mathrm{m}$ (Table 2). 


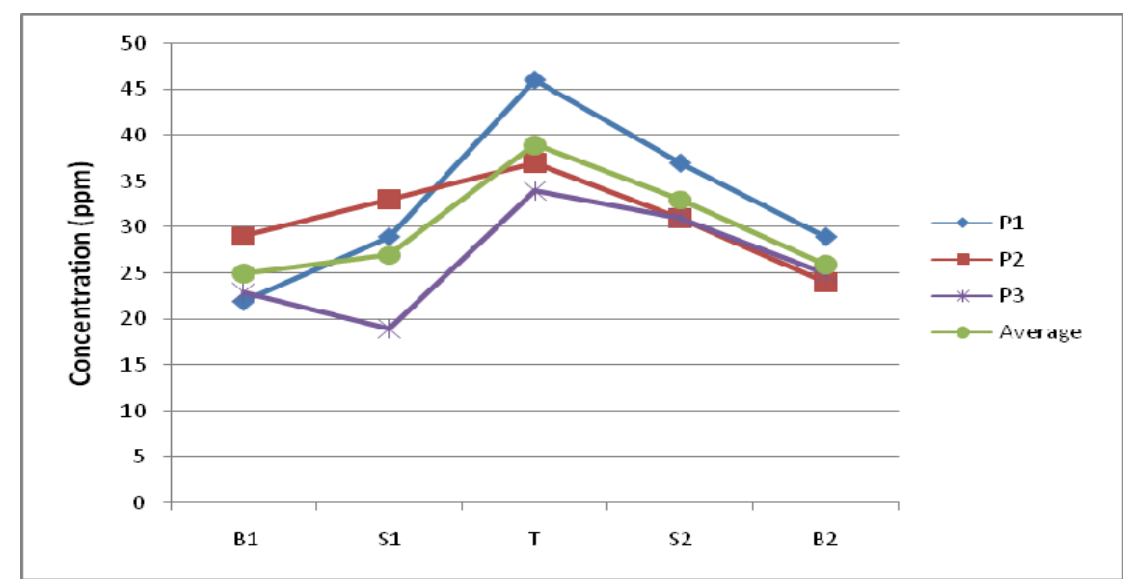

Figure 6

Concentration of $\mathrm{Zn}$ along the profiles over Anomaly 1

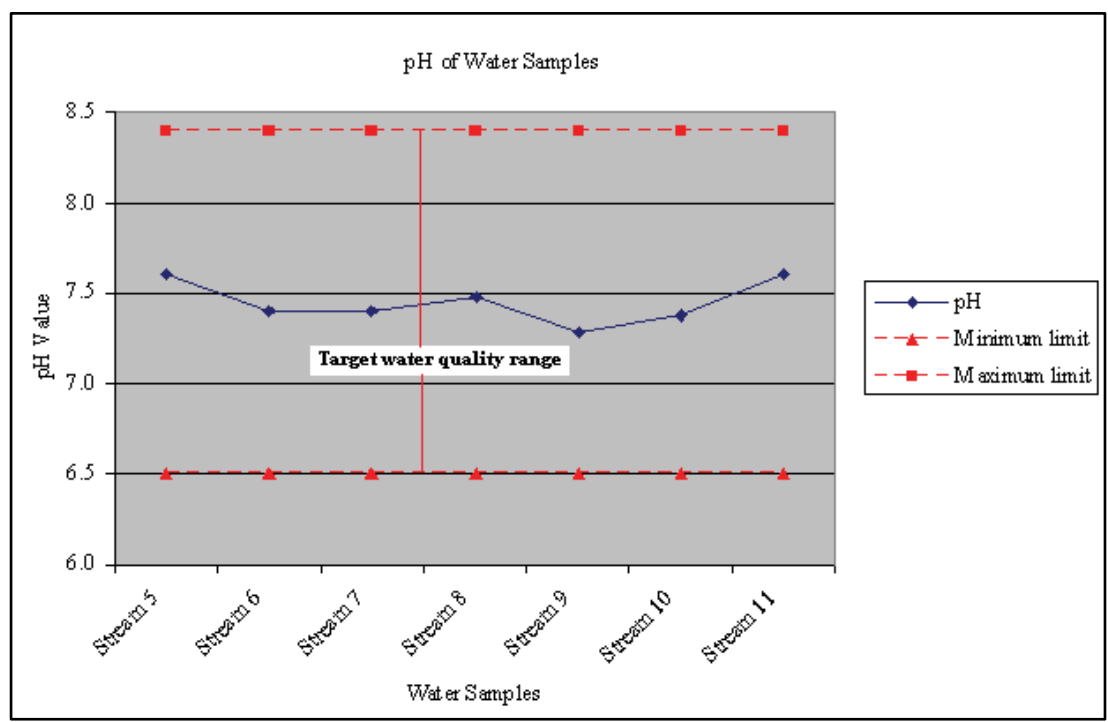

Figure 7

A comparison of the water $\mathrm{pH}$ with the permissible target water quality range

\section{Analysis of major oxides and trace elements}

The geochemical variations of country rocks can be obtained by using $\mathrm{X}-\mathrm{Y}$ scatter graphs, plotting concentrations of major oxides (Rigby et al., 2008).

Consequently, X-Y Scatter graphs were used to plot the concentrations of major oxides, $\mathrm{Al}_{2} \mathrm{O}_{3}$ vs. $\mathrm{Fe}_{2} \mathrm{O}_{3}+\mathrm{MgO} \%$ and $\mathrm{SiO}_{2}$ vs. $\mathrm{Fe}_{2} \mathrm{O}_{3}+\mathrm{MgO} \%$, in order to classify and confirm the rock types (Fig. 8).

Acidic or felsic igneous rocks are defined as rocks with high silica content, greater than $65 \% \mathrm{SiO}_{2}$, but with low ferro-magnesium values. For example, granites and pegmatites have an average $\mathrm{SiO}_{2} \%$ and $\mathrm{Al}_{2} \mathrm{O}_{3} \%$ of $72 \%$ and $14 \%$, respectively (Philpotts et al., 2009). Consequently, the rocks responsible for heavy metal anomalies in this area were found to be felsic, with high silica values and low ferro-magnesian content (Fig. 8). For example, Specimen EDr 2 registered $98.9 \% \mathrm{SiO}_{2}$ (Table 3), which meant that it consists almost entirely of silica (quartz). This rock was confirmed to be quartzite.

Trace element analysis of rock samples revealed high values for some metals within the rock. For example, the concentration of $\mathrm{Pb}$ in pegmatite was between $32-34 \mathrm{mg} / \mathrm{g}$ compared to the background value of $24 \mathrm{mg} / \mathrm{g}$ (Table 4). A similar trend was observed in the case of $\mathrm{Cr}$, which was $6.9 \mathrm{mg} / \mathrm{g}$ and $15 \mathrm{mg} / \mathrm{g}$ in granite, against a background value of $4 \mathrm{mg} / \mathrm{g}$. From this it can be deduced that the heavy metals originated from these rocks and that their elevated values were due to weathering and residual accumulation. This is further confirmed by their values within the dome-shaped structure, with highest values at the top (Fig. 6).

\section{Conclusion}

Based on the analysis of field and analytical data obtained from this study, it was concluded that the heavy metals forming anomalies in the study area were $\mathrm{Pb}, \mathrm{Zn}, \mathrm{Cu}$, As and $\mathrm{Cr}$ with maximum concentrations of 57, 157, 313, 73 and $888 \mathrm{mg} / \mathrm{g}$, respectively. The concentrations of the metals along the streams were high near the anomalies, but decreased downstream.

The anomalies were located over the pegmatite and granite bodies that formed the topographic highs in the area. The occurrence of heavy metal anomalies over the identified pegmatite and granite domes suggests that these rocks were the source of heavy metals and that the anomalous values were due to weathering and residual accumulation with maximum values at the top of the dome.

A comparison of the average concentrations of $\mathrm{Pb}, \mathrm{Zn}$, $\mathrm{Cu}$ and $\mathrm{Cr}, \mathrm{pH}$ and electrical conductivity values with water quality guidelines (DWAF, 996; WHO, 2003; and EPA, 2009)
Plot of major oxides in rock specimens from Ebenezer: $\mathrm{SiO}_{2}$ vs. $\mathrm{Fe}_{2} \mathrm{O}_{3}+\mathrm{MgO} \%$ 
revealed that these parameters meet the water quality requirements at Ebenezer Dam for domestic, agricultural, livestock and aquatic ecosystem uses.

\section{Acknowledgements}

This research was carried out through the financial support solicited by Ms. Cara Maree, the South African Grant-Director, through Prof. Aldo Stroebel of the University of the Free State and this is highly appreciated. We are also thankful to the Council for Geoscience for the supply of maps and analysis of some samples. The bulk of the samples were analysed at the Department of Mining and Environmental Geology, University of Venda, and we are grateful for that.

\section{References}

ALLOWAY BJ and AYRES DC (1997) Chemical Principles of Environmental Pollution. Blackie Academy and Professionals, London. 105 pp.

DWAF (DEPARTMENT OF WATER AFFAIRS AND FORESTRY, SOUTH AFRICA) (1996) South Africa Water Guidelines. Vol. 1-5. ( $2^{\text {nd }}$ edn.). Holmes S (ed.), CSIR, Environmental Services, Pretoria, South Africa.

KRAUSKOPF KB (1967) Introduction to Geochemistry. McGrawHill, New York. 598 pp.
PHILPOTTS AR and AGUE JJ (2009) Principles of Igneous and Metamorphic Petrology ( $2^{\text {nd }}$ edn.). University Press, Cambridge. 148 pp.

PLANT JA, BALDOCK JW and SMITH B (1996) The role of geochemistry in environmental and epidemiological studies in developing countries. In: Appleton JD, Fuge R and McCall GJH (eds.) Environmental Geochemistry and Health. Geological Society Special Publication No. 113. 7-22.

RIGBY M, MOURI H and BRANDL G (2008) P-T conditions and the origin of quartzo-feldspathic veins in metasyenites from the central zone of the Limpopo Belt, South Africa. S. Afr. J. Geol. 111 (2-3) 313-332.

ROSE AW, HAWKES HE and WEBB JS (1979) Geochemistry in Mineral Exploration (2 $2^{\text {nd }}$ edn.). Academic Press, London. $81 \mathrm{pp}$.

SIMPSON PR, ROBOTHAM H and HALL GEM (1991) Regional geochemical orientation studies and the platinum potential of Jamaica. Trans. Inst. Min. Metall. B Appl. Earth Sci. 99 183-187.

SZCZESNIAK HL, ELSENBROEK JH, DU TOIT MC and DE BRUIN D (2001) 2328 Pietersburg: Regional Geochemical Map Series, 1:1000 000. Council for Geoscience, South Africa.

US EPA (UNITED STATES ENVIRONMENTAL PROTECTION AGENCY) (2009) National Recommended Water Quality Criteria. United States Environmental Protection Agency. 1 -22.

WHO (2003) Guidelines for Drinking-Water Quality ( $3^{\text {rd }}$ edn.) Vol. 1. World Health Oganization, Geneva. 488-493.

WHO (1998) Urbanisation and its implications for child health: Potential for action. WHO in collaboration with United Nations Environment Programme. World Health Organization, Geneva. 
Available on website http://www.wrc.org.za ISSN 0378-4738 (Print) = Water SA Vol. 37 No. 2 April 2011 ISSN 1816-7950 (On-line) = Water SA Vol. 37 No. 2 April 2011 